\title{
Kâr Amacı Gütmeyen Kurumlarda Bir Pazarlama Aracı Olarak Gerilla Pazarlama: Gençlik ve Spor Faaliyetleri Örneği
}

\author{
Zafer ÇiMEN ${ }^{1}$, Ömer ÖZBEY² ${ }^{\mathbb{D}}$, Doğukan DOĞAN2* ${ }^{*}$ \\ ${ }^{1}$ Gazi Üniversitesi, Spor Bilimleri Fakültesi, Ankara. \\ ${ }^{2}$ Gençlik ve Spor Bakanlığı, Ankara.
}

Derleme

Gönderi Tarihi: 04.02.2021
Kabul Tarihi: 09.05.2021
DOI: $10.30769 /$ usbd.874388

Online Yayın Tarihi: 30.06.2021

\section{$\ddot{O} z$}

Tüm dünyada geniş kitlelerin takip ettiği spor organizasyonlarındaki artış, teknolojinin iletişim bakımından gelişimi ve spor sektörüne ilginin artması kurumları, hedef kitlesine ulaşma biçimlerinde farklı yollar denemeye sevk etmektedir. Tüketicinin ilgisini çekmek için farklı yöntemler kullanılarak yapılan stratejilerden biri olan gerilla pazarlama, sporun toplumun tüm kesimlerine etkili bir şekilde ulaşabilme özelliğini kullanarak hedef kitleyi etkilemekte birçok avantaj sağlamaktadır. Geleneksel pazarlamadan farklı olarak şaşırtıcı, yenilikçi, dinamik, hayal gücü yüksek ve taklit edilmesi kolay olmayan mesajları sayesinde tüketicilerin bilinçaltını etkilemekte ve istenilen mesajı kalıcı bir şekilde vermektedir. Spor pazarlamasına ilginin artması ve diğer sektörler tarafından spor aracılığıyla yürütülen pazarlama faaliyetleri de göz önünde bulundurulduğunda bu çalışmada, genel olarak pazarlama, gerilla pazarlama ve spor endüstrisinde gerilla pazarlama kavramlarının incelenip ülkemizde kâr amacı gütmeyen gençlik ve spor faaliyetlerinde gerilla pazarlama kullanılarak hedef kitleye ulaşmak ve sunulan hizmetlerin bilinirliğini artırmak amaçlanmaktadır. Bu amaçlara ulaşılabilmesi için kâr amacı gütmeyen gençlik ve spor faaliyetlerinin etkin bir şekilde topluma duyurulabilmesi çalışmada belirtilen gerilla pazarlama örneklerinden yola çıkılarak bu uygulamaların etkili ve verimli bir şekilde kullanılabileceği yapılan araştırma sonucunda değerlendirilmektedir.

Anahtar kelimeler: Pazarlama, gerilla pazarlama, gençlik ve spor.

\section{Guerilla Marketing as a Marketing Tool in Nonprofit Organizations: Youth and Sports Activities Sample}

\begin{abstract}
The increase in sports organizations followed by large masses all over the world, the development of technology in terms of communication and the increasing interest in the sports sector encourage institutions to try different ways to reach their target audience. Guerrilla marketing, which is one of the applied strategies using different methods to attract the attention of the consumer, provides many advantages in influencing the target audience by using the ability of sports to reach all segments of the society effectively. Unlike traditional marketing, it affects the subconscious of consumers and gives intended message permanently thanks to its surprising, innovative, dynamic, imaginative and not easily imitable messages. Considering the increased interest in sports marketing and the marketing activities carried out by other sectors through sports, this study aims to examine marketing in general, guerrilla marketing and guerrilla marketing in the sports industry, and reach the target audience by using guerrilla marketing in non-profit youth and sports activities in our country and increase the awareness of offering services. In order to achieve these goals, it is evaluated as a result of the research that, non-profit youth and sports activities can be announced to the public effectively and that these practices can be used effectively and efficiently based on the guerrilla marketing examples mentioned in the study.
\end{abstract}

Keywords: Marketing, guerrilla marketing, youth and sports.

* Sorumlu Yazar: Doğukan DOĞAN, E-posta: dogukandogan2205@gmail.com 


\section{GíRIŞ}

Günümüzde insanoğlu eğlenme, sağl1k, stresten uzaklaşma, kendini iyi hissetme ve sosyalleşme gibi (Sarol ve Çimen, 2015) birbirinden farklı güdüleyici etkenlerle spor ve rekreasyonel spor etkinliklerine gönüllü olarak katılmaktadır. Yazılı ve görsel medyanın spor organizasyonlarına geniş yer vermesi, sporla ilgili internet kaynaklarının çoğalması, spor turizminin gelişmesi (Parks ve Quertermen, 2007) ve insanların spor etkinliklerine katılım imkânlarının artması, spor endüstrisi içinde kâr amacı güden ve gütmeyen kurumlar için önemli bir pazar oluşturmuştur. Bu gelişmeler spor endüstrisinin son yirmi yılda hızlı büyümesine neden olurken, dünyada ürettiği yaklaşık 388.3 milyar dolarlık (The Business Research Company, 2019) pazardan pay alma çabaları spor haricindeki kurumların da ilgisini çekmektedir. Ayrıca teknolojide yaşanan gelişmelerin bir sonucu olarak tüketicilerin dünyayı yakından izleyebilme olanağı (Dahan ve Levi, 2012) tüketici davranış ve alışkanlıklarında oluşan yeni düzenle farklılaşmıştır (Bulunmaz, 2016; Schwarz ve Hunter, 2008). Bu yeni durum başta küçük işletmeler ve kâr amacı gütmeyen kurumlar olmak üzere spor endüstrisi içinde yer alan aktörlerin hedef kitleye ulaşmak için farklı pazarlama çabaları içine girmelerine neden olmuştur. Örneğin bir kişi günlük ortalama 4.000 ile 10.000 reklama maruz kaldığı göz önünde bulundurulduğunda (Forbes, 2017), tüketicilerin iletilen mesajlara zaman içerisinde duyarsızlaştı̆̆ı ve büyük bütçelerle hazırlanan reklamların istenilen hedeflere ulaşmada etkisiz kaldığı görülmektedir.

Dolayısıyla kurumlar tüketicilerin ilgisini çekmek ve tüketim davranışlarını etkilemek için farklı pazarlama strateji ve araçları kullanma çabaları içine girmektedir (Bozbay, 2015; Kaleli, 2018). Bu çabaların birçok örneği olmasına karşın en dikkat çekici olanlarından biri gerilla pazarlamadır. Çünkü gerilla pazarlama kâr amacı güden ve gütmeyen kurumlar için hedef pazara ulaşmada fazla para harcamadan pazarlama amaçlarını gerçekleştirmede kolaylık sunmaktadır (Memişoğlu, 2014; Şimşek, 2013). Bu özelliği ile pazarlamaya ayırabilecekleri para açısından düşük bütçeli kurumlarca yürütülen gerilla pazarlama, yıllar içinde büyük bütçeli kurumların da dikkatini çekmiş ve pazarlama çabaları içinde sıkça kullanılan bir araç haline gelmiştir (Levinson, 2007).

Bu noktadan hareketle, bu çalışmada öncelikle hedef kitleye faklı yollarla ve düşük maliyetle ulaşma olanağı sağlayan gerilla pazarlamanın ortaya çıkışı, kullanılma amacı ve gelişimi ile gençlik ve spor alanında kullanılmasına yönelik örnekler üzerinde durulacaktır. Bu genel değerlendirme sonrasında gençlik ve spor hizmetlerini toplumun geneline ulaştırılma görev ve sorumluluğunu üstlenen Gençlik ve Spor Bakanlığı, sunulan hizmetlerin bilinirliğini ve faaliyetlere katılımı artırmak, kamusal faydayı ön plana çıkarmak ve toplumsal duyarlılığa vurgu yapmak amacıyla gerilla pazarlamanın neden kullanılabilir olduğu açıklanmaya çalışılacaktır. 


\section{Kavramsal Çerçeve}

\section{Ortaya Çıkışı, Kullanılma Amacı ve Gelişimiyle Gerilla Pazarlama}

Toplumun ihtiyaçlarıyla, bu ihtiyaçları karşılama arasında bağlantı kurarak, mal ve hizmetleri tüketicilere tanıtma görevi olarak değerlendirilen pazarlamanın (Masteralexis, Barr ve Hums, 2019; Tek,1991) amac1, kurumlar tarafindan sunulan ürün ya da hizmetin yeni tüketicilere ulaştırılmasını sağlamak ve hâlihazırdaki tüketicileri tatmin ederek onları elde tutmaktır (Çimen, Eraslan ve Halıcı, 2019; Kotler ve Armstrong, 2018). Bu amacı gerçekleştirebilmek için kurumlar, bütçelerinin önemli bir kısmını pazarlama faaliyetleri için ayırmaktadır. Ayrılan bu bütçelerin büyüklüğüne göre kurumlar kendilerini hedef kitlelerine ulaştıracak pazarlama araçlarına karar verip uygulamaktadır. Ancak tüketicilerin satın alma kararlarını etkilemek ve ilgilerini çekebilmek için kullandıkları pazarlama faaliyetlerinde (Bozbay, 2015; Kaleli, 2018) büyük bütçelerle yola çıkan kurumlar, düşük bütçeli olanlara göre daha avantajlı hale gelmektedir. İşte bu küçük bütçeli kurumların da rekabette hedef kitlelerine ulaşma kolaylığı sağlayacak düşük maliyetli pazarlama araçları arayışının bir sonucu olarak ortaya çıkan pazarlama araçlarından biri de gerilla pazarlamadır.

İspanyolların Fransızlara karşı 1804-1814 tarihleri arasında kullandığı, güçsüz olan tarafın belirli taktikler uygulayarak karşı tarafı zihinsel ve fiziksel olarak yıpratma, avantajlı olmayan durumları avantaja çevirme temeline dayanan bir savaş stratejisi olan gerilla kavramı (Kaya, 2011; Uysal, 2011), pazarlama faaliyetlerinde ilk defa 1984 y1lında Jay Conrad Levinson tarafından kullanılmıştır. $\mathrm{Bu}$ sıra dışı ve beklenmeyen yöntemlerle tüketicinin ilgisini çekmeye dayanan pazarlama taktiği (Bigat, 2012), Levinson tarafindan bütçesi küçük ama hayalleri büyük girişimciler için "Gerilla pazarlama” olarak adlandırmıştır (Levinson, 1998).

Alanyazında birçok tanımı olan gerilla pazarlamanın tanımlarında yer alan ortak özellikler geleneksel olmayan, sıra dışı, dinamik, şaşırtıcı ve etkili pazarlama yöntemlerini kullanma olarak sıralanabilir (Alena, 2012). Bu farklı özellikleriyle gerilla pazarlamanın dünya çapında bilinirliği 1990'lı yıllardan itibaren giderek arttırmıştır. Dünyada meydana gelen ekonomik krizler, ülkelerin siyasal yapılarında yaşanan değişimler, soğuk savaşın sona ermesi ile artan küreselleşme hareketleri ve benzeri gelişmeler gerilla pazarlama gibi yeni pazarlama araçlarının da yaygın kullanılması için uygun ortam oluşturmuştur (Arslan, 2009).

Oluşan bu ortam içinde doğru şekilde uygulandığında oldukça önemli sonuçlar alınmasını sağlayan gerilla pazarlama (Memişoğlu, 2014) günümüzde büyük- küçük, yerel-ulusal, kamuözel ayırımı olmaksızın yaygın bir şekilde kullanılmaktadır. Gerilla pazarlamanın yaygın kullanımına neden olan temel sebeplerin başında düşük bütçeler ile mal ya da hizmetin tanıtımına katkı sağlamasıdır. Bunun yanında gerilla pazarlamanın geleneksel pazarlama yöntemlerinin dışına çıkarak ilgi çekici mesajlarla tüketiciye ulaşması ve tüketiciyi şaşırtarak iletilmek istenilen mesajı tüketicinin bilinçaltına yerleştirmedeki etkililiği de gerilla pazarlamanın kullanılma nedenleri arasında sayılabilir (Alena, 2012). Bu farklı yönleriyle gerilla pazarlamayı kullanan kurumlar, geleneksel pazarlama yöntemlerinin dışına çıkarak amaçlarına en düşük pazarlama maliyetlerle erişirken ilgi çekici, sıra dışı ve akılda kalıcı mesajlarla satış öncesinde, esnasında ve sonrasında tüketicilere alışılmışın dışında deneyimler 
sunma fırsatı da yakalamaktadır (Funk, 2008; Memişoğlu, 2014; Yüksekbilgili, 2011). Gerilla pazarlamanın ruhunda olan bu yaratıcı fikir ve sıra dışı hayal gücü benzer şekilde sporun doğasında da bulunmaktadır. Dolayısıyla spor sektörünü diğer sektörlerden ayıran bu özelliğiyle birlikte dinamik yapısı, gerilla pazarlamanın spor sektöründe kullanılması için iyi bir zemin oluşturmaktadır (Ünal, 2013).

\section{Örneklerle Gençlik ve Spor Faaliyetlerinde Gerilla Pazarlama}

Gençlik ve Spor Bakanlığı sosyal sorumluluk, bağımlılıktan kurtulma, gönüllülük konularında farkındalık oluşturma ile spor aracılığıyla sağlıklı yaşam anlayışının toplumda yaygınlaştırılması, spor yapma konusunda davranış değişikliğinin sağlanması gibi hususlarda kendisine verilen gençlik ve sporla ilgili görevleri yerine getirmektedir.

Bakanlık, kişilerin fiziksel ve ruhsal olarak sağlıklarını kaybetmelerine ve dolayısıyla toplumun işlevselliğinin deforme olmasına neden olan bağımlılık konusunda eğitim ve farkındalık yaratma gibi faaliyetleri de yürütmektedir. Öncelikli olarak madde bağımlılığı konusunda gençlere yönelik çeşitli projeler desteklense de Bakanlığın bu faaliyetlerinin kamuoyunda bilinirliği sınırlı kalmaktadır. Madde bağımlılığının etkilerine dikkat çekmek için bağımsız bir kurum tarafından sigara bağımlılığının etkilerini göstermede kullanılan kül tablası örneğinde (Görsel 1) olduğu gibi gerilla pazarlama anlayışı ile beklenmedik ve şaşırtıcı bir şekilde toplumun dikkatini çekmek ve bilinirliği artırmak mümkün olabilir.
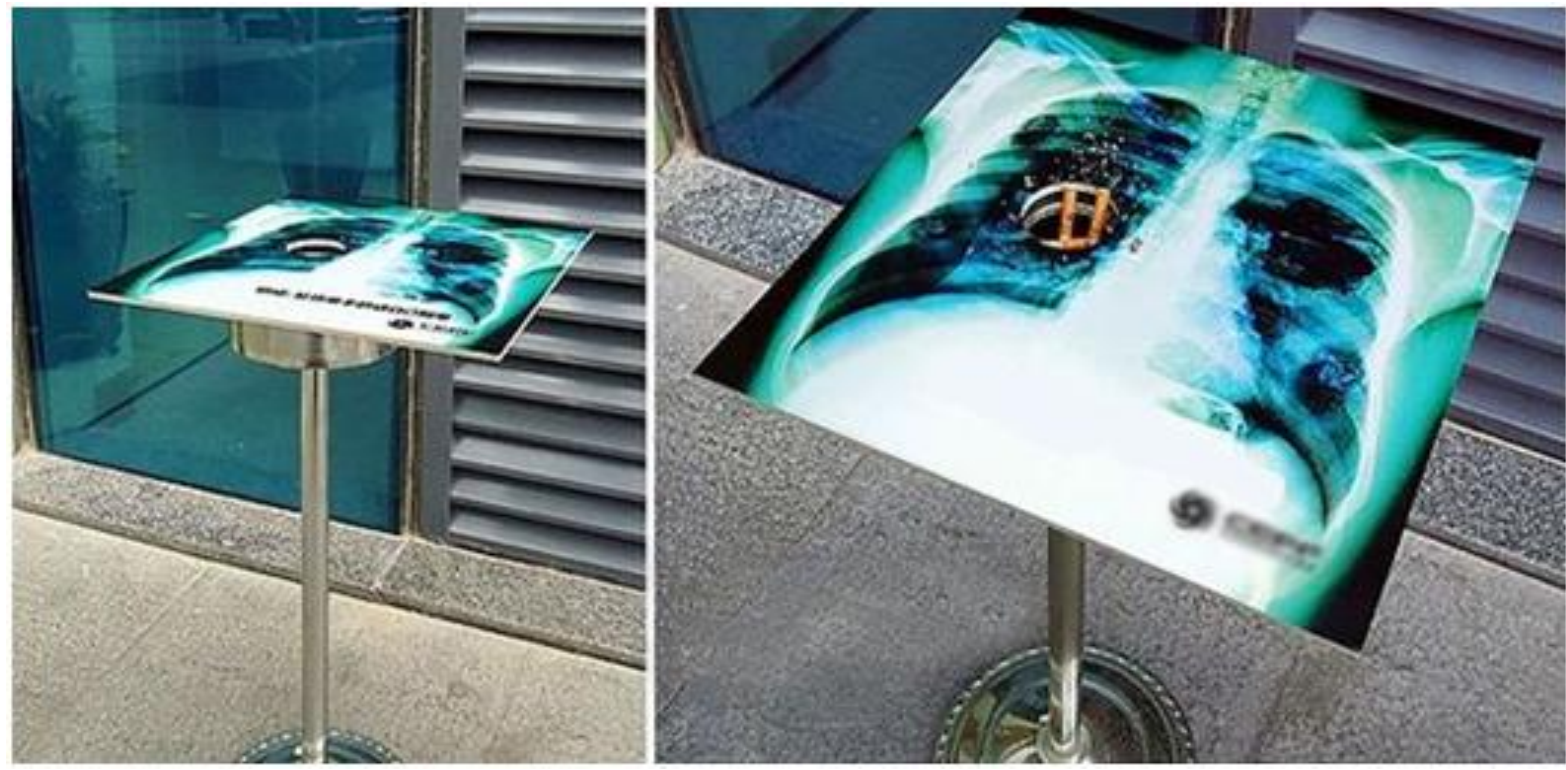

Görsel 1. Sigara Bağımlılı̆̆ı ile mücadele için tasarlanan görsel.

Gençlik ve Spor Bakanlığı tarafından yürütülen faaliyetlerden bir diğeri ise gönüllülük faaliyetleridir. Gençler arasında gönüllülük bilincini artırmak ve gönüllülük ile ilgili özendirici faaliyetlerde bulunmak amacıyla gençlerin gönüllülük faaliyetlerine katılımlarını teşvik etmek ve bu faaliyetleri desteklemek Bakanlığın görev ve sorumluluğunda yer almaktadır (Gençlik ve Spor Bakanlığı, 2019). "Küçük özverilerle büyük işler başarmaya hazırsanız hepinizi gönüllü olmaya davet ediyoruz” sloganıyla gönüllülük etkinlikleri gerçekleştiren ve 2019 yılını gönüllülük yılı ilan eden Bakanlık, bu kapsamda birçok faaliyet 
düzenlemektedir (Gençlik ve Spor Bakanlığı, 2019). Bu faaliyetlerinden birisi olan kan bağışı, Bakanlığın tüm merkez ve taşra teşkilatı ile Türk Kızılayı tarafından 81 il ve 350 noktadan yürütülmektedir (Gençlik ve Spor Bakanlığı, 2019). Hiç bir beklenti içerisinde bulunulmadan tamamen gönüllü olarak yapılan kan bağışı, kişilerin iyi niyetli davranışlarının neticesi olarak değerlendirilmektedir. Kan bağışı, ihtiyaç sahibi kişilere yardımcı olmak ve toplumda iyilik yapmaya istekli kişilerin artmasına sebep olmaktadır (Hablemitoğlu, Özkan ve Yıldırım, 2010). Kan bağışı yapma farkındalığı oluşturmaya çalışılan kan ünitesi örneğinde (Görsel 2) olduğu gibi gerilla pazarlama anlayışı ile toplumda kan bağışı yapma davranışının kazandırılmasına katkı sağlanabilir.

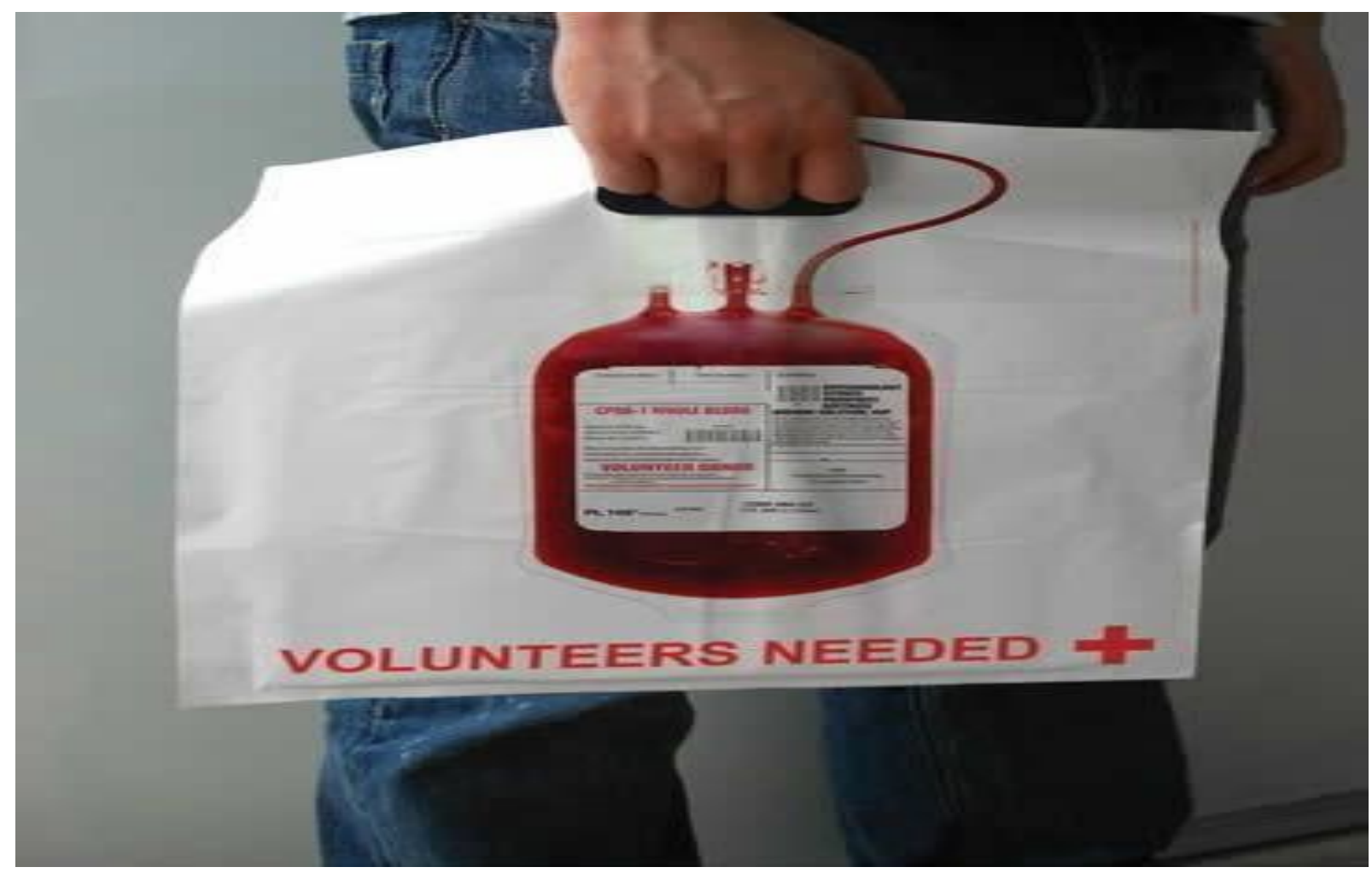

Görsel 2. Kan bağışında bulunma farkındalığının artırılması ile ilgili görsel.

Değişen dünya, farklılıkların bir arada yaşamasını kaçınılmaz kılmakta ve bu farklılıklara duyarlılık anlayışının hızla yükselişini beraberinde getirmektedir. Ne var ki toplumsal yaşamda farklılıklara duyarlılık anlayışını söylemden eyleme dönüştürmek için çeşitli proje ve araştırmaların yapılmasını gerekli kılmaktadır. Önemli bir farklılık kaynağı olan engelliliğe ilişkin tutumların değiştirilmesi, engelli bireylerin toplumsal olarak duyarlılığın oluşturulması ve olumlu tutumların yaşama bürünmesi oldukça önemlidir (Pegem, 2020).

Engelli bireyler için farkındalık oluşturmak ve engelli bireylerle empati kurabilmenin hedeflendiği otobüs durağı örneğinde (Görsel 3) olduğu gibi toplumsal olarak engellilik konusuna dikkat çekilmesi sağlanabilir. 

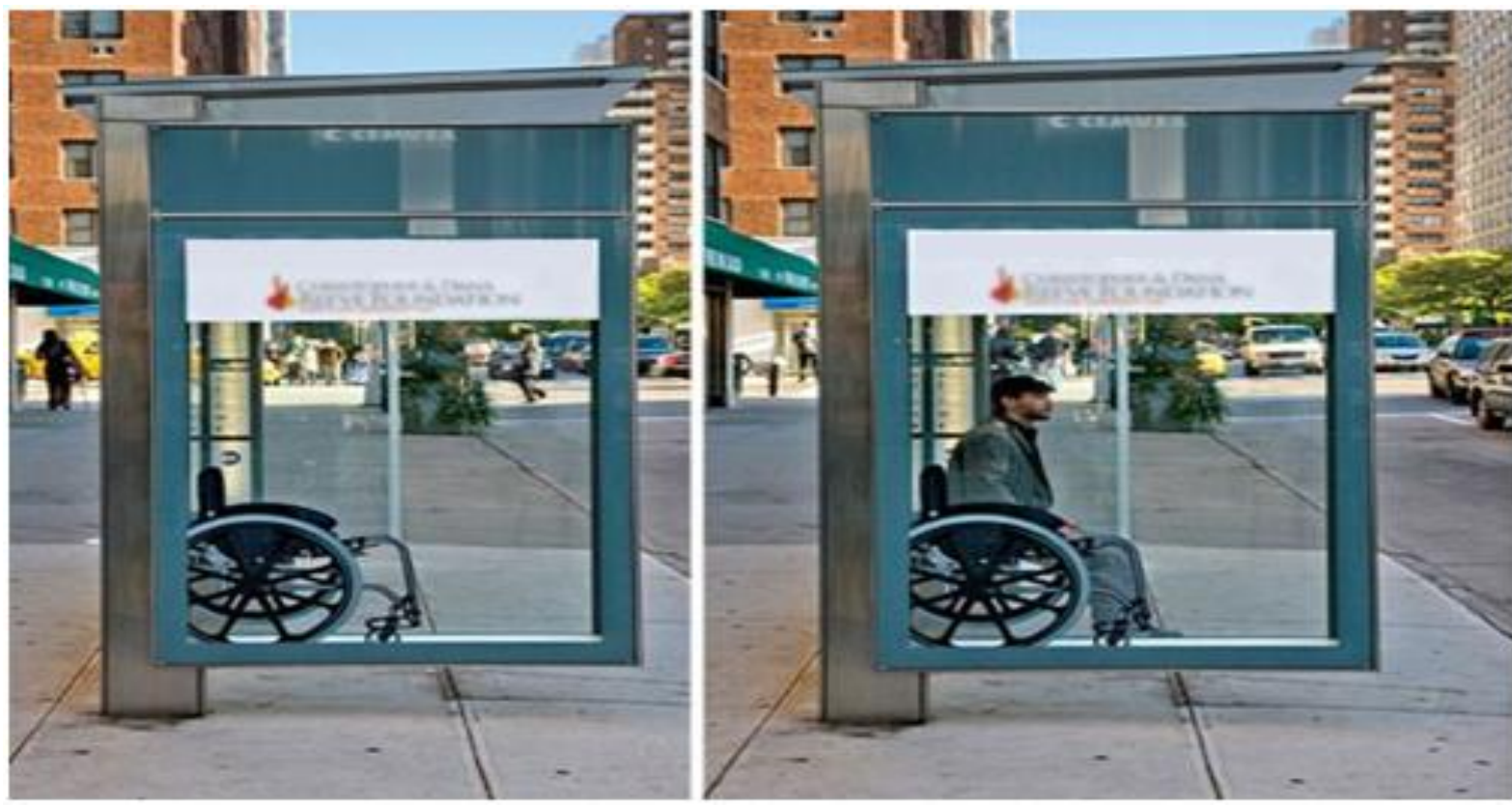

Görsel 3. Engelli bireylerle empati kurabilmek için tasarlanan görsel.

Engelli bireylerin topluma entegrasyonu için fiziksel aktivite ve spor yapabilmelerinin sağlanması ve bu kapsamda spor eğitim programlarının geliştirilerek engelli bireylere yönelik bilgilendirme ve bilinçlendirme çalışmalarının yapılması (Cumhurbaşkanlığı Kararnamesi 2018; On Birinci Kalkınma Planı, 2019), dezavantajlı gençlerin hareketliliğine yönelik projelerin öncelikli olarak desteklenmesi Bakanlığın görev ve sorumlulukları arasında yer almaktadır. Engelli bireylerin fiziksel hareketliliğini artırarak spor yapmaya teşvik edilebilmelerini sağlamak için araç park yeri ve tabela işareti örneğinde (Görsel 4 ve 5) olduğu gibi düzenlemeler mümkün k1lınabilir.
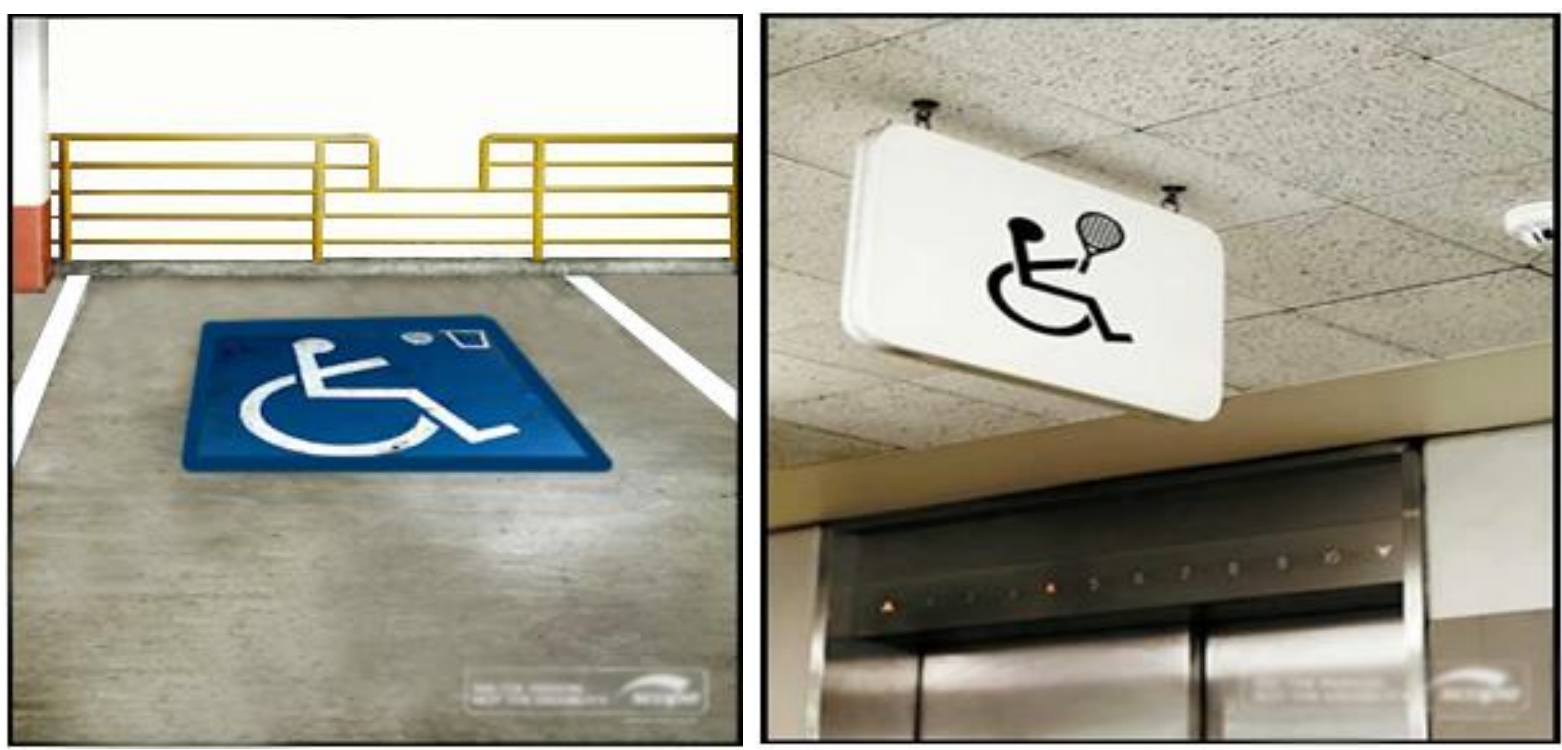

Görsel 4-5. Engelli bireyleri fiziksel hareketliliğe teşvik eden görsel.

Gençlik ve Spor Bakanlığının sosyal sorumluluk politikaları çerçevesinde çevre kirliliği probleminin azaltılarak ortadan kaldırılması için bireylere temiz çevre bilincinin 
kazandırılması gerekmektedir. Bu bilincin bireysel ve toplumsal olarak aşılanabilmesi ve temiz çevre farkındalığının oluşturulabilmesi için farklı uygulamalar ve politikalar yürütülmektedir (Ulusal Gençlik ve Spor Politikası Belgesi, 2013).

Çevre kirliliğinin önlenmesi ve doğal kaynakların verimli kullanılabilmesi için geri dönüşüm hakkında gerekli bilgilendirmenin yapılması ve sürdürülebilir bir çevre bilincinin kazandırılması gerekmektedir (Birleşmiş Milletler Kalkınma Programları, 2020). Gençlere bu bilincin kazandırılması ve gençlerin çevre sorunları ile ilgili farkındalıklarının arttırılması konusunda etkili ve uygulanabilir politikalar oluşturulmak, geri dönüşüm noktalarının yaygınlaştırılmasını sağlamak ve kullanımını teşvik ederek gençlerde çevre duyarlılı̆̆ının arttırılmasını sağlayacak uyarıcı mesajlar içeren programlar hazırlanmak Bakanlık ile paydaş kurum ve kuruluşların işbirliği içerisinde yürütmesi gereken faaliyetler arasındadır (Çevre ve Şehircilik Bakanlığı, 2017; Ulusal Gençlik ve Spor Politikası Belgesi, 2013).

Farklı sektörlerin spor aracılığıyla misyonlarını gerçekleştirmeye çalıştıkları göz önünde bulundurulduğunda spor ile geri dönüşüm bilincinin oluşturulması geri dönüşüm kutuları örneğinde (Görsel 6) olduğu gibi başarılı bir yöntem ile ele alınmaktadır. Bu çalışma basketbol sporunu araç olarak kullanarak atık maddelerin geri dönüşümünü istenilen şekilde gruplandırılması sağlanabilir.

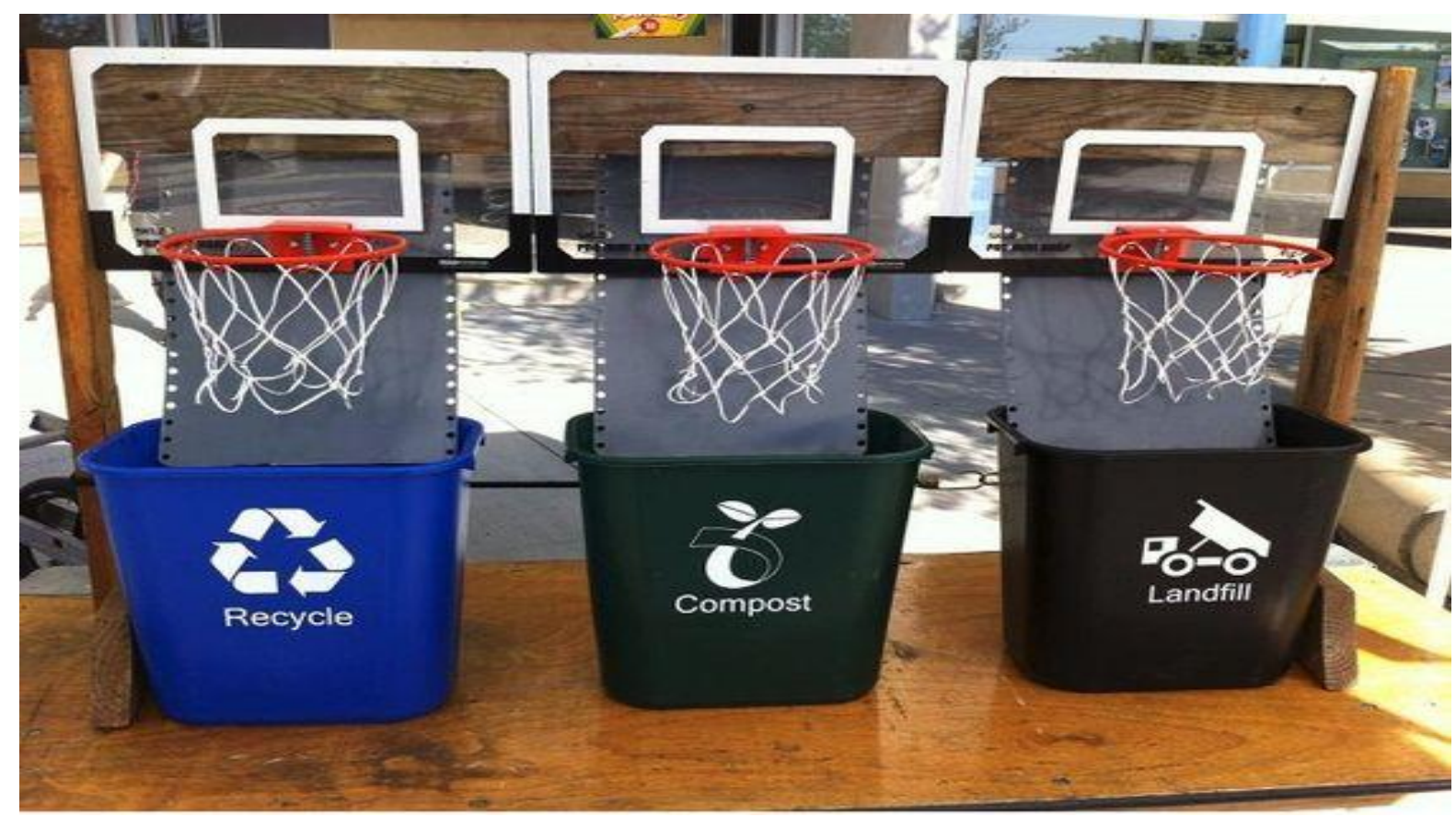

Görsel 6. Spor branşı ile geri dönüşümün sağlandığı görsel.

Günümüzde teknolojinin gelişmesiyle beraber sosyal hayat içerisinde fiziksel hareketin yeri azalmaya başlamıştır. Teknolojinin bu yönde değişimi sosyal yaşamı kolaylaştırmasına rağmen toplum sağlığını olumsuz yönde etkilemektedir. Bireylerin günlük gereksinimlerini bilgisayar başından kolayca karşılayabilmesi toplumda hareketsiz yaşama bağlı olarak önemli sağlık sorunlarına yol açmaktadır (Aktaş ve Özdil, 2016). Hareketli yaşamın insan sağlığı için önemini vurgulamayı amaçlayan park ve bahçelerde oturma yerleri örneğinde (Görsel 7) 
olduğu gibi hareketli yaşamı teşvik ederek sosyal sorumluluk projelerinin önemi vurgulanabilir.
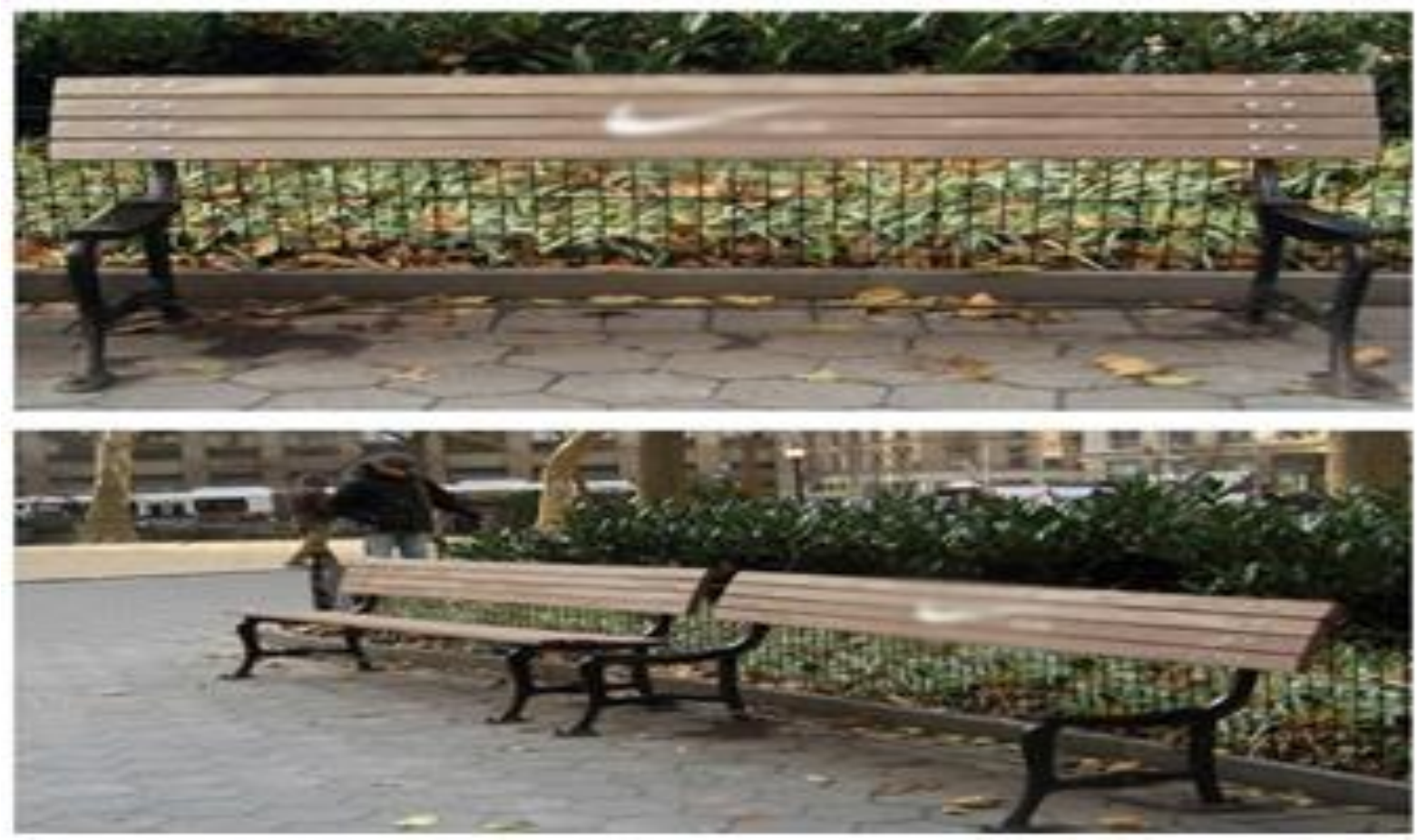

Görsel 7. Hareketli yaşamı destekleyen görsel.

Genç nüfus yapısının korunması, yaşlıların yaşam kalitesinin yükseltilmesi için hayata aktif bir şekilde katılımın sağlanması ile yüksek yaşam standartlarının oluşturularak aktif yaşlanma ortamlarının oluşturulması kalkınma planlarında da desteklenmektedir (On Birinci Kalkınma Planı, 2019). Hareketliliği artırabilmek için yürüyen merdiven yerine fiziksel olarak merdiven kullanmayı teşvik eden metro istasyonu örneğinde (Görsel 8) olduğu gibi topluma hareketli bir yaşam biçimi benimsetilebilir.

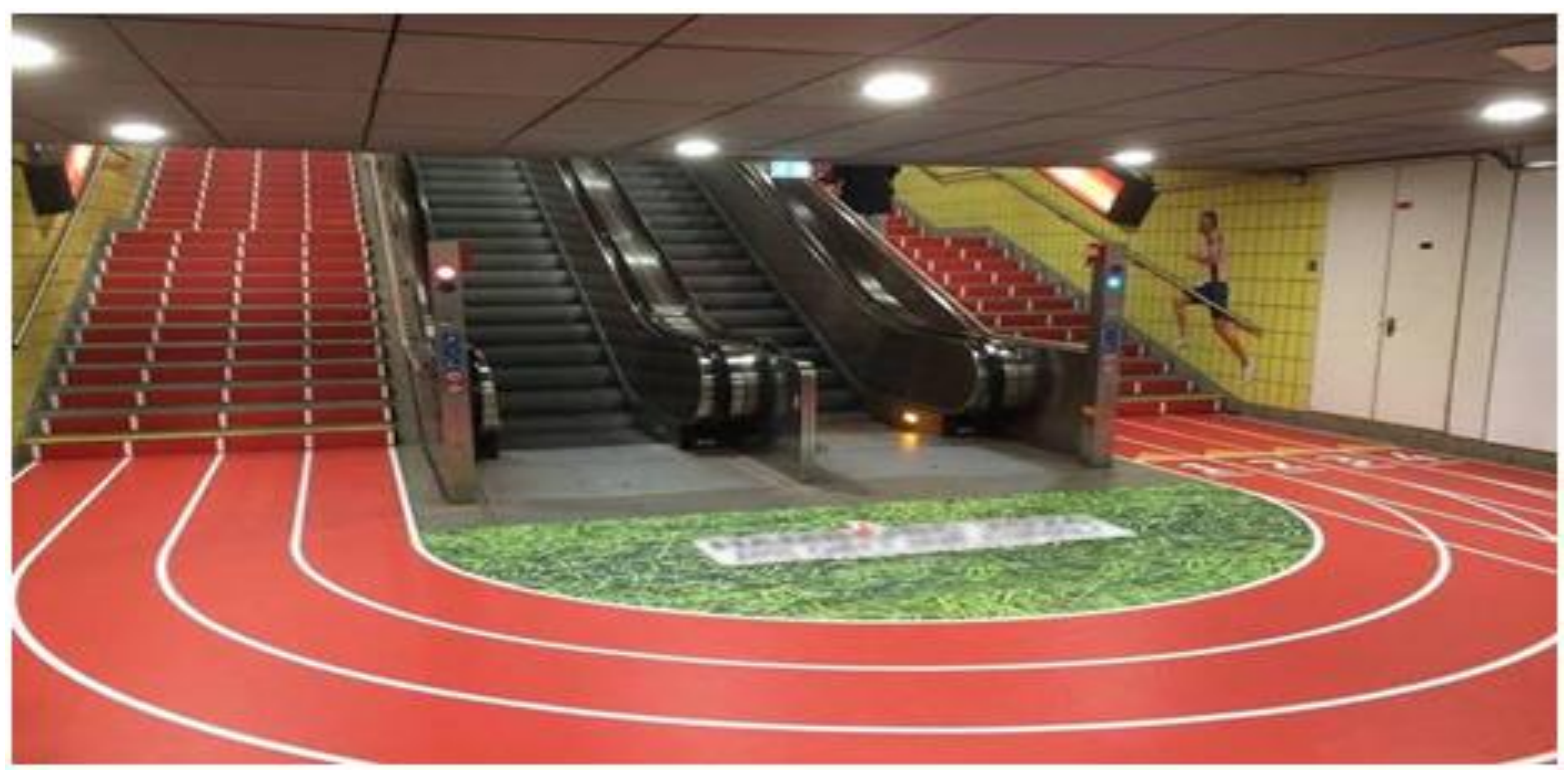

Görsel 8. Hareketli yaşamı destekleyen görsel. 
Ulusal Gençlik ve Spor Politikası Belgesi'nde (2013) yer alan hedeflerden biri de gençlerin sağlığının korunmasına yönelik önlemlerin arttırılmasıdır. $\mathrm{Bu}$ hedef, gençlerin kronik hastalıklardan korunmalarını sağlamak için sağlık bilinçlerini geliştirerek fiziksel hareketliliğin sağlanması, spor aracılığıyla sağlıklı yaşam için spor faaliyetlerinin geliştirilmesi, yaygınlaştırılması ve spora katılımın artırılması gibi sorumluluklar Bakanlığın stratejik planlarında da yer almaktadır (Gençlik ve Spor Bakanlığı, 2019). Bu amaç ve hedeflerinin gerçekleştirilebilmesi ve etki alanının genişletilebilmesi için Gençlik ve Spor Bakanlığı merkez ve taşra teşkilatı ile yerel yönetimler, üniversiteler ve diğer kâr amacı gütmeyen paydaş kurum ve kuruluşların işbirliği içerisinde bu faaliyetleri yürütmesi gerekmektedir. Spor kültürünün oluşturulması amacıyla toplu taşıma araçları kullanan kişilerde farkındalık oluşturma örneğinde (Görsel 9, 10 ve 11) olduğu gibi farklı spor temalı giydirmeler yapılabilir.

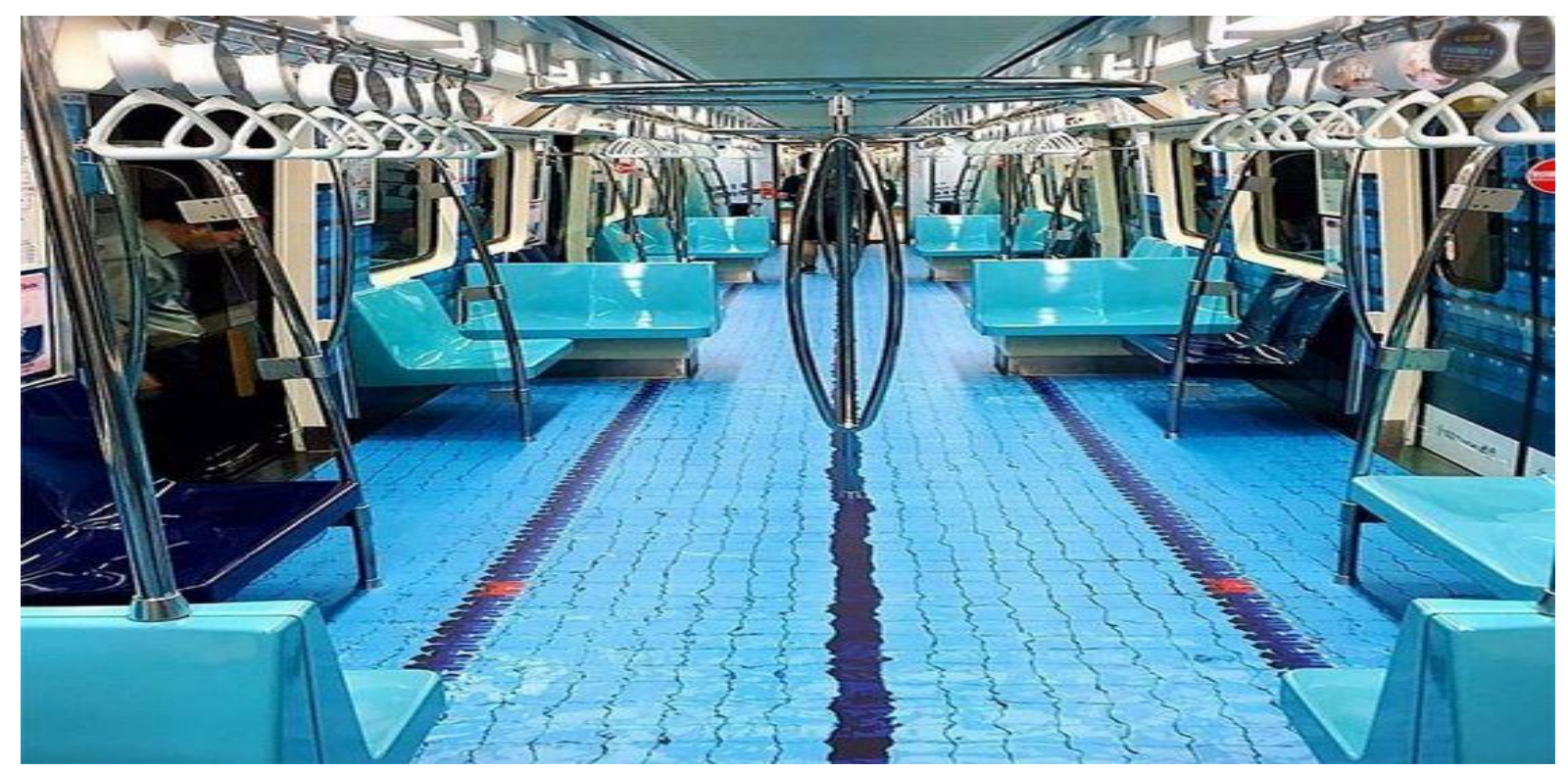

Görsel 9. Toplu taşıma araçlarına yüzme havuzu temalı zemin giydirmeleri.

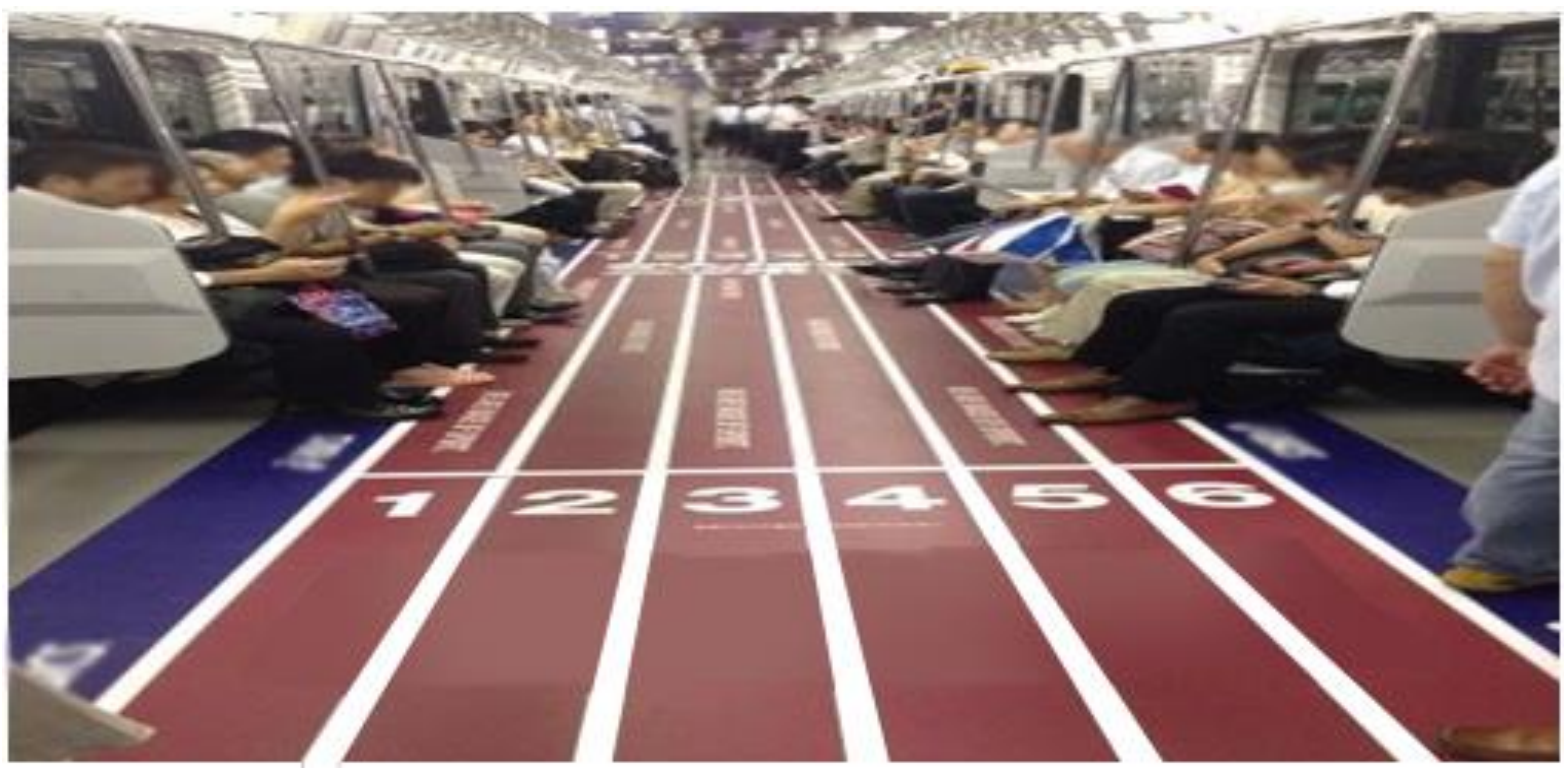

Görsel 10. Toplu taşıma araçlarına atletizm pisti temalı zemin giydirmeleri. 


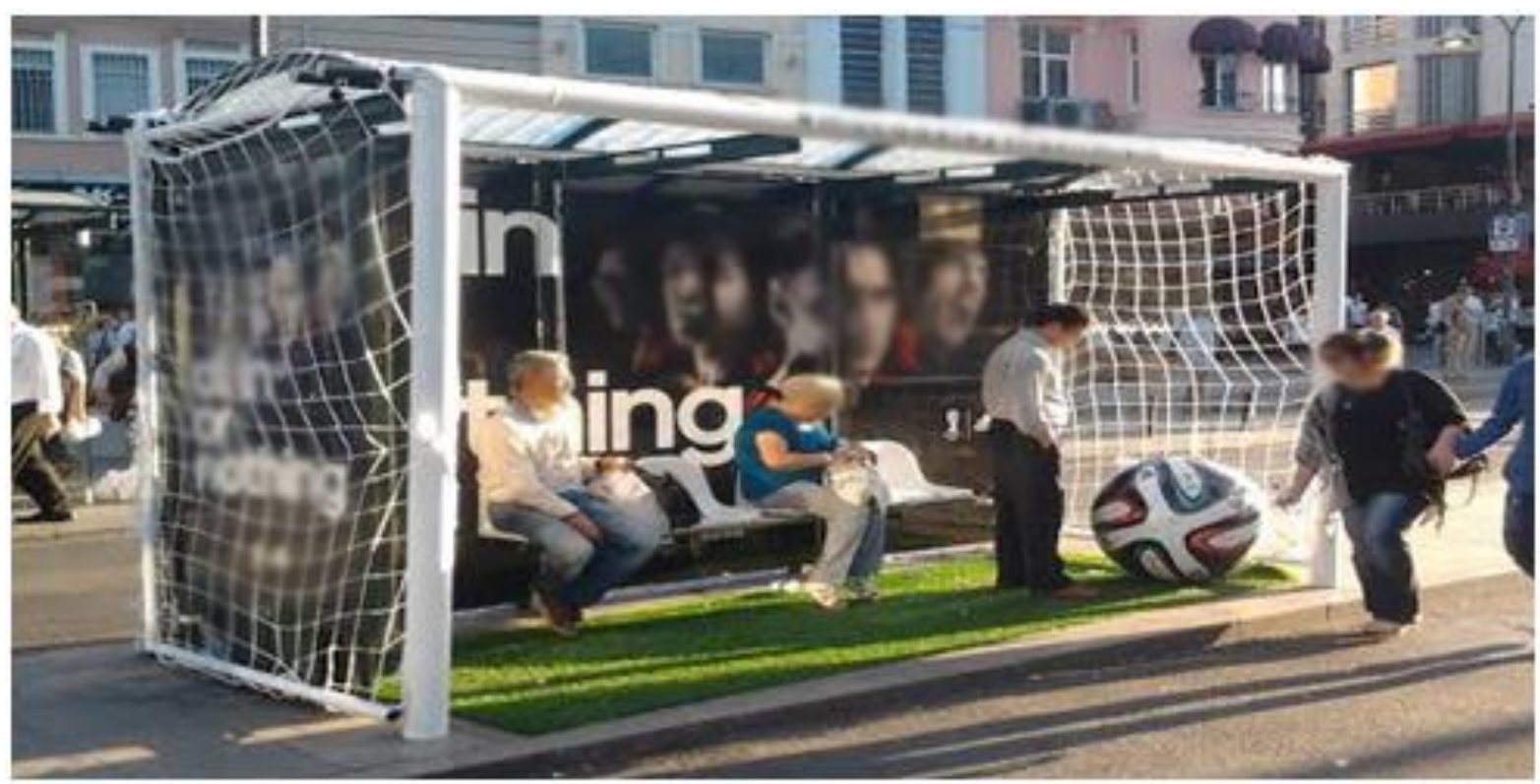

Görsel 11. Toplu taşıma duraklarına spor temalı giydirmeler.

Toplumsal olarak spora olan ilginin arttırılması amacıyla farkındalık çalışmaları ile çeşitli kampanyaların yapılması ve bu kapsamda sanatsal, kültürel ve sportif etkinliklerin gerçekleştirilmesi gerekmektedir (Belediye Kanunu, 2005; On Birinci Kalkınma Planı, 2019). Yerel yönetimlerin bünyesinde milyonlarca vatandaş tarafından kullanılan toplu taşıma hizmetlerine spor temalı çalışmaların yerleştirilmesi sayesinde toplumun fiziksel aktiviteye ve aktif spora katılımının arttırılması ve bu faaliyetlerin toplumda sürdürülebilir hale getirilmesi amaçlanmaktadır.

\section{SONUÇ}

Ürün ve hizmetlerin hızlı bir şekilde tüketildiği günümüzde gerek kâr elde etme amacıyla kurulan işletmeler gerekse kâr amacı gütmeyen kamu kurum ve kuruluşları farklı pazarlama taktikleri ile hedef kitlelerine ulaşarak kurumsal bilinirliklerini artırmayı amaçlamaktadır.

Teknoloji ve medya araçlarının gelişmesiyle birlikte tüketicilere ulaşmakta kullanılan pazarlama faaliyetlerinin kullanımı hız kazanmıştır. Kişilerin çok sayıda pazarlama aracına maruz kalmaları sebebiyle vermiş oldukları tepki kurumsal olarak beklentiyi karşılayamamaktadır. Kurumsal politikaların hedef kitle üzerindeki etkisinin artırılması amaciyla daha önce benzerine rastlanılmayan pazarlama faaliyetleri kullanan gerilla pazarlama ile hedef kitle üzerinde istenilen ilgi sağlanmaya çalışılmaktadır (Levinson ve Godin, 1994; Levinson ve Hanley, 2006).

Kâr amacı gütmeyen ve kamusal hizmet sunan Gençlik ve Spor Bakanlığı görev ve sorumluluklarını yerine getirirken toplumun ilgisini çekmeyi, düzenlediği faaliyetlere katılımı artırmay1, toplumsal olarak bedenen ve ahlaken iyi bir vatandaş olma halini kişilere benimsetmeyi, gençlik faaliyetlerine katılım ile spor kültürü bilincini kalıcı ve sürdürülebilir bir şekilde gerçekleştirmeyi amaçlamaktadır. Bakanlığın bu amaçlara ulaşabilmesi için kurumsal bir marka oluşturarak bilinirliğini arttırması ve bu sayede faaliyetlerini etkin bir 
şekilde duyurabilmesi amacıyla görsellerde belirtilen örneklerden yola çıkılarak gerilla pazarlama uygulamalarının etkili ve verimli bir şekilde kullanılabileceği düşünülmektedir.

Yayın Etiği: $\mathrm{Bu}$ çalışmanın hazırlanma ve yazım sürecinde "Yükseköğretim Kurumları Bilimsel Araştırma ve Yayın Etiği Yönergesi” kapsamında bilimsel, etik ve alıntı kurallarına uyulmuş olup; toplanan veriler üzerinde herhangi bir tahrifat yapılmamış ve bu çalışma herhangi başka bir akademik yayın ortamına değerlendirme için gönderilmemiştir.

Çıkar Çatışması: Yazarlar arasında herhangi bir çıkar çatışması yoktur.

Araştırmacıların Katkı Oranı Beyanı: Yazarlar araştırmanın her aşamasına eşit katkıda bulunmuştur. 
Çimen, Z., Özbey, Ö. ve Doğan, D. (2021). Kâr amacı gütmeyen kurumlarda bir pazarlama aracı olarak gerilla pazarlama: Gençlik ve spor faaliyetleri örneği. Ulusal Spor Bilimleri Dergisi, 5(1), 13-25.

\section{KAYNAKLAR}

Aktaş, S. ve Özdil, G. (2016). Ankara barosu spor hukuku kurulu Av. Hasan Aydın Tansu armağanı. Ankara: Ankara Barosu.

Alena, K. (2012). Guerilla marketing: New concept in practice sport master case. Thesis (Bachelor), Mikkeli University of Applied Sciences, Mikkeli.

Çevre ve Şehircilik Bakanlığı. (2017). Ambalaj Atıkları Kontrolü Yönetmeliği. https://www.resmigazete.gov.tr/eskiler/2017/12/20171227-12.htm.

Arslan, S. (2009). Turizm sektöründe alternatif bir pazarlama stratejisi olarak gerilla pazarlamanın kullanılması: Konaklama işletmeleri üzerine bir araştırma. Yayımlanmış Yüksek Lisans Tezi, Gazi Üniversitesi, Eğitim Bilimleri Enstitüsü, Turizm İşletmeciliği Eğitimi Anabilim Dalı, Ankara.

Belediye Kanunu. (2005). Belediyenin görev ve sorumluluklart. https://www.mevzuat.gov.tr/MevzuatMetin/1.5.5393.pdf.

Bigat, E. Ç. (2012). Guerrilla advertisement and marketing. Procedia-Social and Behavioral Sciences Journal, $51,1022-1029$.

Birleşmiş Milletler Kalkınma Programları. (2020). UNDP Türkiye sürdürülebilir kalkınma amaçları. https://www.tr.undp.org/content/turkey/tr/home/sustainable-development-goals/goal-11-sustainablecities-and-communities.html.

Bozbay, Z. (2015). Pazarlama stratejileri. İstanbul: İstanbul Üniversitesi Açık ve Uzaktan Eğitim Fakültesi, İşletme Lisans Programı.

Bulunmaz, B. (2016). Gelişen teknolojiyle birlikte değişen pazarlama yöntemleri ve dijital pazarlama. TRT Akademi Dijital Medya Sayısı, 1(2), 348-365.

Cumhurbaşkanlığı Kararnamesi. (2018). 1 Sayılı Cumhurbaşkanlı̆̆ı Teşkilatı hakkında Cumhurbaşkanlığı Kararnamesi. https://www.mevzuat.gov.tr/MevzuatMetin/19.5.1.pdf.

Çimen, Z. Eraslan, A. ve Halıcı, A. (2019). Yönetim ve Spor. Ankara: Gazi Kitabevi.

Dahan, G. ve Levi, E. (2012). Reklam ajanslarının gerilla pazarlama uygulamaları: Türkiye örneklemi üzerinden bir inceleme, İstanbul Üniversitesi İletişim Fakültesi Dergisi, 42, 37-47.

Forbes. (2017). Finding brand success in the digital world. https://www.forbes.com/sites/forbesagencycouncil/2017/08/25/finding-brand-success-in-the-digitalworld/\#73eca182626e.

Funk, C. (2008). Consumer behaviour in sports and events: Marketing action. Australia: Griffith Business School, Department of Tourisim Leisure Hotel and Sport Management.

Gençlik ve Spor Bakanlığı. (2019). Genç gönüllüler. https://www.gencgonulluler.gov.tr/Blog/Detail /9.

Gençlik ve Spor $\quad$ Bakanlığı $\quad$ (2019). Stratejik $\quad$ plan $2019-2023$. http://www.gsb.gov.tr/public/edit/files/StratejikPlan2019-2023.pdf.

Hablemitoğlu, P. Özkan, D. ve Yıldırım, U. (2010). Bir fedakâkarlık örneği olarak "kan bağışı", Sosyal Politika Çalışmaları Dergisi, 20(20), 67-78.

Kaleli, S. (2016). Sosyal pazarlamada gerilla uygulamalar. Trakya Üniversitesi Sosyal Bilimler Dergisi, 20(2), 313-336.

Kaya, S. (2011). Pazarlamada yeni bir çı̆̆ır açılıyor: Bütçesi küçük hayalleri büyük girişimciler için gerilla pazarlama. İzir Ticaret Odasi Ar\&Ge Bülten, 8, 27-34.

Kotler, P. ve Armstrong, G. (2018). Pazarlama ilkeleri. (Çev. E. Gegez). İstanbul: Beta Basım Yayın Dağıtım. 
Çimen, Z., Özbey, Ö. ve Doğan, D. (2021). Kâr amacı gütmeyen kurumlarda bir pazarlama aracı olarak gerilla pazarlama: Gençlik ve spor faaliyetleri örneği. Ulusal Spor Bilimleri Dergisi, 5(1), 13-25.

Levinson, C. J. ve Hanley, J. (2006). Tüketicilerin bilinçaltını fethetmek için gerilla pazarlama devrimi. (Çev. Y. Fetcher). İstanbul: Mediacat Yayınları.

Levinson, C. J. (1998). Guerrilla marketing. USA: Houghton Mifflin Company.

Levinson, C. J. (2007). Guerrilla marketing. USA: Houghton Mifflin Company, Fourth Edition.

Levinson, C. J. and Godin S. (1994). The guerilla harketing handbook. USA: Houghton Mifflin Company.

Masteralexis, L. P. Barr A. ve Hums, A. (2019). Spor yönetimi. (Çev. H. Kasap). Ankara: Atlas Akademik Basın Yayın Dağıtım.

Memişoğlu, A. (2014). Gerilla pazarlama faaliyetlerine ilişkin tüketici görüş ve değerlendirmelerinin belirlenmesi: Örnek bir uygulama, Yayımlanmış Yüksek Lisans tezi, Atılım Üniversitesi, Sosyal Bilimler Enstitüsü, Ankara.

On Birinci Kalkınma Planı, (2019, Temmuz). Nitelikli insan, güçlü toplum. http://www.sbb.gov.tr/wpcontent/uploads/2019/07/OnbirinciKalkinmaPlani.pdf.

Parks, J. \& Quertermen, B. (2007). Managing sport in the 21 st century. USA: Contemporary Sport Management Human Kinetics Publications, Third Edition.

Pegem, (2020). Özel eğitim kongresi özel eğitimde ölçme ve değerlendirme sempozyumu. https://www.pegem.net/Akademi/kongrebildiri_detay.aspx?id=137648.

Sarol, H. ve Çimen, Z. (2015). The effects of adapted recreational physical activity on the life quality of individuals with autism. The Anthropologist, 21(3), 522-527.

Schwarz, C. E. ve Hunter, D. J. (2008). Advanced theory and practice in sport marketing. USA: British Library Cataloguing in Publication, Second Edition.

Şimşek, G. (2013). Pazarlama iletişimi “gayrı-resmi” silahı: Tuzak pazarlama ve uygulanan stratejiler. Selçuk Üniversitesi İletişim Dergisi, 5(1), 135-143.

Tek, Ö. B. (1991). Pazarlama ilkeler ve uygulamalar. İzmir: Memleket Gazetecilik ve Matbaacılık.

The Business Research Company. (2019). Global Sports Market Value. https://www.thebusinessresearchcompany.com/report/sports-market.

Ulusal Gençlik ve Spor Politikası Belgesi. (2013, Ocak 27). Gençlik politikaları. https://www.gsb.gov.tr/public/edit/files/Mevzuat/ ulusal_genclik_ve_spor_politikasi.

Uysal, S. (2011). Küçük ve orta ölçekli işletmeler için yeni bir pazarlama anlayışı: Gerilla pazarlama. Yayımlanmış Yüksek Lisans Tezi, Atılım Üniversitesi, Sosyal Bilimler Enstitüsü, Ankara.

Ünal, H. (2013). Gerilla tarzı pazarlama ve spor. Ankara Üniversitesi Spor Bilimleri Fakültesi Dergisi, 11(2), $61-71$.

Yüksekbilgili, Z. (2011). Gerilla pazarlama: Kuramsal bir çerçeve. Anadolu Bilimleri Meslek Yüksekokulu Dergisi, 22, 49-54.

Bu eser Creative Commons Atıf-Gayri Ticari 4.0 Uluslararası Lisansı ile lisanslanmıştır. 